\title{
THE ROLE OF LONELINESS IN THE RELATIONSHIP BETWEEN SOCIAL ANXIETY AND SUBJECTIVE WELL-BEING: USING THE SOCIAL PHOBIA INVENTORY (SPIN) AS A MEASURE
}

Antonija MARIČIĆ, Marina ŠTAMBUK Centre for Croatian Studies, Zagreb

UDK: 159.942 .4

Izvorni znanstveni rad

Primljeno: 21. 5. 2015.

The purpose of this study was to test the mediating role of loneliness in the relationship between social anxiety and subjective well-being while taking into account the multidimensionality of social anxiety. Reaching this aim was preceded by examining the psychometric properties of the Croatian translation of the SPIN on a sample of 202 students. The results show support for the one-dimensional structure of the SPIN. However, it has also been shown that several items of the inventory may be redundant and that a 2 -factor structure (12 items) fits the data better. The first factor was described as "observation situations and negative evaluation", while the second represented "social avoidance and fear". The total SPIN score showed convergent and divergent construct validity as well as high levels of internal consistency and test-retest reliability. Loneliness fully mediated the relationship between social anxiety and subjective well-being. The symptoms of social anxiety that contribute to its relation with subjective well-being through loneliness are those related to the concerns of being negatively evaluated or merely observed by others when experiencing or doing something.

Keywords: social anxiety, SPIN, loneliness, subjective well-being Zagreb, Borongajska cesta 83d, 10000 Zagreb, Croatia. E-mail: amaricic@hrstud.hr 
Humans as social beings have a strong need to be liked and approved by others. Due to the importance and the functional nature of social relationships they naturally fear and worry about social situations and possible rejection.

Social anxiety (SA) is a common human experience characterized by an intense fear of evaluation from others in social situations (Morrison \& Heimberg, 2013). It manifests itself on a continuum encompassing everything from shyness to a severely disabling clinical diagnosis of social anxiety disorder (SAD) or social phobia (SP) (e.g., Miskovic \& Schmidt, 2012). While some individuals with SA may endure social interactions with certain discomfort and distress, for others, the fear may be overwhelming and induce behavioral avoidance of social situations. Because of its severe impact on everyday life and occupational functioning, avoidance behaviour is the greatest source of impairment in SA. Usually feared and avoided social situations include being in the center of attention or watched while doing something, public speaking, talking to authorities, attending parties (Holt, Heimberg, \& Hope, 1992; Toit \& Stein, 2003). Blushing, twitching and stammering are typical somatic symptoms of SA, along with general symptoms of anxiety, such as palpitations, tremors, sweating, gastrointestinal discomfort, muscle tension (Toit \& Stein, 2003). Undoubtedly, SA individuals recognize that their fear is unreasonable and excessive, still they experience difficulties when coping with it.

$\mathrm{SAD}$ is one of the most common psychiatric disorders, with high comorbidity with other anxiety, mood or substance abuse disorders (e.g., Lampe, Slade, Issakidis, \& Andrews, 2003). Its life-time prevalence ranges from 7 to $12 \%$ (Kessler et al., 2005). Despite the fact that effective therapeutic approaches for SA are increasing, a large number of affected individuals avoid seeking treatment (Wang et al., 2005). Sex differences observed in many other anxiety disorders are less pronounced in social anxiety (McNeil, 2010), or even not significant (Craske, 2003).

Given the importance of social connections to subjective well-being, further research on SA and social relationships is needed. Also, for the purpose of better understanding SA effects in everyday functioning, it is important to test how different dimensions or symptoms of social anxiety are interrelated with subjective well-being and social relations.

\section{Measuring social anxiety}

General agreement exists about the SA definition, but the nature and number of dimensions that sufficiently represent this concept is still uncertain. The idea that SA varies along a 
DRUŠ. ISTRAŽ. ZAGREB GOD. 24 (2015), BR. 3 STR. $407-426$

MARIČIĆ, A., ŠTAMBUK, M. THE ROLE OF.. severity continuum enjoys significant support, but the literature on its subtypes is also considerable (McNeil, 2010). For instance, the subtypes can be distinguished on the basis of the number of situations feared by person: generalized SA (fear of most social/performance situations) and nongeneralized SA (fear of few social/performance situations) (Toit \& Stein, 2003). Additionally, distinct clusters of feared situations can be distinguished like performance related and social interaction related concerns (e.g., Hughes et al., 2006), or fear of observation situations, such as being watched while working (Cox, Clara, Sareen, \& Stein, 2008). Finally, clinically differentiated SA components are: fear, avoidance, and physiological symptoms (APA, 2013)

Along with the growing awareness and high prevalence of SAD, a number of self-rated and interview-based measurements were developed. Connor et al. (2000) summarize shortcomings of these instruments as being lengthy and usually focused on only one SA aspect. Taking into account the limitations of existing measures, these authors developed Social Phobia Inventory (SPIN). This inventory covers the full spectrum of clinically important symptoms in a variety of situations: subjective fear, avoidance behavior and physiological discomfort. Due to its brevity, sensitivity, and easy scoring format, the SPIN is becoming a popular SA measure (Letamendi, Chavira, \& Stein, 2009) in clinical and research settings, and has been translated into many languages.

SPIN authors have found a 5-factor structure using exploratory factor analysis (EFA). They described the factors as: fear and avoidance of talking to strangers and in social gatherings (1st factor), criticism and embarrassment (2nd factor) and people in authority (4th factor); physiological changes (3rd factor) and avoiding being the center of attention and of public speaking (5th factor). In contrast to expectations, a theoretically and clinically proposed 3-factor solution did not emerge. To our knowledge, only Radomsky et al. (2006) confirmed this structure, although psychometric properties of subscales were not as strong as those of the total SPIN score. Other researchers found support for one-dimensional (e.g., Garcia-Lopez, Bermejo, \& Hidalgo, 2010), as well as three (e.g., Caballo, Salazar, Irurtia, Arias, \& Nobre, 2013; Carleton et al., 2010; Gori et al., 2013) and five factor solutions (e.g., Nagata, Nakajima, Teo, Yamada, \& Yoshimura, 2013). Although some solutions from different studies had the same number of factors, those factors varied in their component items and the assessed SA dimensions. In general, a somewhat different factor structure fits clinical samples better than nonclinical ones (e.g., Carleton et al., 2010; Nagata et al., 2013). Subsequently, 
DRUŠ. ISTRAŽ. ZAGREB GOD. 24 (2015), BR. 3, STR. $407-426$

MARIČIĆ, A., ŠTAMBUK, M.: THE ROLE OF.
SPIN authors developed Mini-SPIN, a 3-item version of the inventory, demonstrating sound psychometric properties (Connor, Kobak, Churchill, Katzelnick, \& Davidson, 2001), which indicates that some original items may be redundant. Overall, findings of the factor structure diversity indicate that clinically differentiated SA components are not crucial in measuring $\mathrm{SA}$, and that distinct feared situations clusters seem more important. This factor diversity can also be attributed to study sample characteristics and applied statistical analysis.

Nevertheless, it is important to note that in numerous studies the original total SPIN score has had excellent internal consistency, test-retest reliability, convergent and discriminant validity as well as sensitivity to the changes in SAD severity following both psychological and pharmacotherapy treatment (Antony, Coons, McCabe, Ashbaugh, \& Swinson, 2006; Radomsky et al., 2006).

\section{Social anxiety, loneliness and subjective well-being}

When social fear becomes maladaptive, it can severely affect everyday life, such as social relationships and subjective well-being. Subjective well-being (SWB) refers to how people experience and evaluate the quality of their lives (Diener \& Ryan, 2009). These evaluations include judgments and feelings regarding satisfaction with life, work, relationships, health, meaning, purpose, and other life domains. Previous research suggested that SWB has an important role in health and longevity, as well as work and income (Diener \& Biswas-Diener, 2008; Diener, Nickerson, Lucas, \& Sandvik, 2002; Diener \& Ryan, 2009). Furthermore, SWB contributes to society as a whole, because people with high SWB engage more frequently in altruistic and prosocial activities (Tov \& Diener, 2008).

The number of social relationships correlates positively with SWB (e.g., Diener \& Biswas-Diener, 2008; Kahneman \& Krueger, 2006). Numerous clinical and non-clinical studies have revealed that SA is strongly associated with a smaller social network (Falk Dahl \& Dahl, 2010). Moreover, SA individuals reported reduced social support (e.g., Ruscio et al., 2008), fewer friends, greater rates of living alone, and a significantly lower prevalence of club/association membership and activity (Falk Dahl \& Dahl, 2010). In addition to smaller social networks, SA is associated with fewer close relationships, such as intimate friendships or romantic partnerships (e.g., Chou, Liang, \& Sareen, 2011), and lower rates of marriage or marriage-like relationships (Falk Dahl \& Dahl, 2010). In accordance with the relationship findings above, individuals with SA reported greater loneliness (Falk Dahl \& Dahl, 2010; for review see Teo, Lerrigo, \& Rogers, 2013). Loneliness 
DRUŠ. ISTRAŽ. ZAGREB GOD. 24 (2015), BR. 3 STR. $407-426$

MARIČIĆ, A., ŠTAMBUK, M. THE ROLE OF... not being met by the quantity or especially the quality of one's social relationships (Alden, Regambal, \& Plasencia, 2014). It seems that the best part in people's days are when they are around others and involved in social interaction, so it is not surprising that individuals with SA perceive a lower level of SWB (e.g., Eng, Coles, Heimberg, \& Safren, 2005). When asked specifically, SA individuals were particularly dissatisfied with the quality of their social functioning and achievement (Eng et al., 2005).

\section{THE PRESENT STUDY}

The first aim was to assess the psychometric properties of the Croatian translation of the SPIN. Construct validity was evaluated by comparing the one-dimensional structure based on the evidence of the total SPIN score as reliable, valid and sensitive (e.g., Antony et al., 2006), the 3-factor structure theoretically and clinically relevant (APA, 2000), the original 5-factor structure (Connor et al., 2000) and the factor structure identified in the present study. Convergent and divergent validity were assessed as well as reliability measures.

The second aim was to test the mediating role of loneliness in the relation of social anxiety and SWB while taking into account the multidimensionality of social anxiety.

\section{Proposed hypotheses:}

H1: It is expected that the SPIN is multidimensional, but due to different findings and theoretical considerations, the hypothesis regarding the exact number of dimensions was not formed. The total SPIN score is expected to be reliable and valid.

$\mathrm{H} 2$ : It is expected that the effect of SA on SWB is mediated by loneliness. Specifically, increased SA is associated with increased feelings of loneliness which is in turn associated with decreased SWB. Moreover, SA symptoms that mainly affect the quality of social relationships are expected to contribute to the relation of SA with SWB through loneliness.

\section{METHOD}

\section{Participants}

The study sample consisted of 226 students from the University of Zagreb (Centre for Croatian Studies, Faculty of Education and Rehabilitation Sciences, Faculty of Humanities and Social Sciences). Since the percentage of male students in the aforementioned study groups is very low, only 24 male subjects participated. Therefore, only female participants $(N=202)$ 
were included in further analysis, aged between 18 and 31 $(M=21.76, S D=2.24)$.

\section{Procedure}

With the author's permission, the original SPIN was translated to Croatian using back-translation. Original and back-translated SPIN were compared by the author of the inventory and a satisfactory equivalent in meaning was estimated.

University teachers recruited their students as participants via E-mail. All participants gave informed consent and completed the online survey lasting around 15 minutes voluntarily. In return, participants received course credit. Test-retest reliability coefficient was obtained over a 6-month interval on 55 participants. Out of those who registered, $84 \%$ completed the study battery.

\section{Measures}

The Social Phobia Inventory (SPIN; Connor et al., 2000) is a self-report instrument comprising 17 items evaluated on a five-point Likert scale, ranging from 0 ("not at all") to 4 ("extremely"). Items were designed to assess three SA components: subjective fear, avoidance behavior and physiological discomfort. Participants rated how much the described problems had bothered them over the past week. The full range of total score is 0-68, with higher scores reflecting higher levels of social anxiety.

Brief Fear of Negative Evaluation Scale (Brief-FNE; Leary, 1983) is a self-report instrument that assesses the concern over negative evaluation by others, which is one of the theoretically assumed social anxiety features. The Brief-FNE consists of 12 items rated on a five-point Likert scale, ranging from 0 ("not at all") to 4 ("extremely characteristic of me") while four items are reverse-scored $(3,4,7,10)$. The full range of total score is $0-48$, with higher scores reflecting higher levels of fear of negative evaluation. As well as the original, the Croatian version has demonstrated test-retest reliability, internal consistency and one-dimensional structure (Bezinović, 1988). For the current sample, internal consistency was high $(\alpha=0.92)$.

Beck Depression Inventory-Second Edition (BDI-II; Beck, Steer, $\&$ Brown, 2011) is a 21-item, self-report measure of depression severity in adults and adolescents. Answer options include four increasing levels of severity from 0 to 3 . The full range of total score is $0-63$, with higher scores indicating greater severity of depressive symptoms in the last two weeks. The Croatian version is reliable, valid and diagnostically accurate (Jakšić, Ivezić, Jokić-Begić, Surányi, \& Stojanović-Špehar, 2013). Internal consistency for the current sample was high $(\alpha=0.90)$. 
DRUŠ. ISTRAŽ. ZAGREB GOD. 24 (2015), BR. 3 STR. $407-426$

MARIČIĆ, A., ŠTAMBUK, M. THE ROLE OF...
Subjective well-being (SWB) was measured by seven indicators of Personal Well-Being Index (PWI) and one that measures life satisfaction in general. The PWI is a subscale of the International Well-Being Index (Cummins, Eckersley, Pallant, Van Vugt, \& Misajon, 2003) that measures the subjective dimension of quality of life. Using the scale from 1 ("completely unsatisfied") to 10 ("completely satisfied") participants rated their satisfaction within seven aspects of life: standard of living, personal health, achievements in life, personal relationships, community-connectedness, personal safety, and future security. Using the same scale, Global life satisfaction (GLS) was assessed by the single item: "How satisfied are you with your life as a whole?" (International Wellbeing Group, 2013). The internal consistency of the PWI scale was good $(\alpha=0.87)$, and Cronbach's $\alpha$ for all eight items was 0.89 . The full range of total score is $8-80$, with higher scores indicating greater SWB.

The short version of University of California Los Angeles Loneliness Scale (UCLA; Allen \& Oshagan, 1995) is a 7-item one-dimensional scale that measures the general state of loneliness. Items are rated on a five-point Likert scale, ranging from 1 ("not at all") to 5 ("extremely characteristic of me"). The full range of total score is 7-35, with higher scores indicating greater loneliness. The Croatian version is one-dimensional and internally consistent (Lacković-Grgin, Penezić, \& Nekić, $2002)$. For the current sample, internal consistency was good $(\alpha=0.85)$.

\section{RESULTS}

\section{Psychometric properties of SPIN}

\section{Construct validity}

First we performed confirmatory factor analysis (CFA) to calculate fit indices for one-dimensional, 3-factor, and 5-factor models based on the literature (CFA and SEM were performed in Mplus 6; Muthén \& Muthén, 2010). We used the recommended absolute, comparative and parsimonic indices (Brown, 2006; Hu \& Bentler, 1999). A common measure of model fitness, $\chi^{2}$, is fairly sensitive to sample size, thus we used alternative index: $\chi^{2} / d f$ ratio. For the model to have an acceptable fit, it is necessary that the $\chi^{2} / d f$ ratio is $<3$, indices SRMR (Standardized root mean square residual) and RMSEA (Root mean square error of approximation) $<0.08$ and CFI (Comparative fit index) and TLI (Tucker-Lewis Index) $>0.90$.

None of the initial models resulted in acceptable fit (Table 1). Only for the one-dimensional model did the modification indices suggest correlating error terms that produced improvement of fitness to an acceptable level. Suggested modifica- 
DRUŠ. ISTRAŽ. ZAGREB GOD. 24 (2015), BR. 3, STR. $407-426$

MARIČIĆ, A., ŠTAMBUK, M.: THE ROLE OF..

(1) TABLE

Indices of model fitness for SPIN models tions are justified given the items' face value. Some of the item pairs have the same object (e.g., being criticized) but the difference is whether their content is about fear or avoidance. The remaining pairs describe distress when experiencing physiological symptoms in front of others. For other models, modification indices suggested unjustified re-specifications that would considerably change the initial model: correlating error terms for items loading on different factors and loading items on the factors not specified by the initial model.

\begin{tabular}{|c|c|c|c|c|c|c|c|c|}
\hline \multirow[b]{3}{*}{ Model } & & \multirow{2}{*}{\multicolumn{4}{|c|}{ Absolute }} & \multicolumn{3}{|c|}{ Indices of model fitness } \\
\hline & & & & & & Compa & ative & $\underline{\text { Parsimonic }}$ \\
\hline & & (p) & $d f$ & $\chi^{2 / d f}$ & $S R M R$ & CFI & TLI & RMESA \\
\hline \multirow{4}{*}{$\begin{array}{l}\text { Models based } \\
\text { on literature }\end{array}$} & 1-factor & $419.49(<0.001)$ & 119 & 3.53 & 0.08 & 0.74 & 0.70 & 0.11 \\
\hline & 1-factora & $204.96(<0.001)$ & 113 & 1.81 & 0.06 & 0.92 & 0.90 & 0.06 \\
\hline & 3-factor & $357.01(<0.001)$ & 116 & 3.08 & 0.08 & 0.79 & 0.75 & 0.10 \\
\hline & 5 -factor & $324.11(<0.001)$ & 95 & 3.41 & 0.14 & 0.77 & 0.71 & 0.11 \\
\hline \multirow{2}{*}{$\begin{array}{l}\text { Model based } \\
\text { on EFA results }\end{array}$} & 2-factor & $161.37(<0.001)$ & 53 & 3.04 & 0.07 & 0.85 & 0.81 & 0.10 \\
\hline & 2 -factorb & $75.22(<0.012)$ & 50 & 1.50 & 0.04 & 0.96 & 0.95 & 0.05 \\
\hline
\end{tabular}

Note. a Error terms correlated for items 10 and 4, 8 and 3, 5 and 12, 11 and 9, 7 and 2, and 17 and $13 ;$ b Error terms correlated for items 10 and 4,8 and 3 and 5 and 12 .

Since none of the tested models based on literature, resulted in good fit we performed EFA to determine primary factors and eliminate unstable items. EFA was performed using principal factor analysis with promax rotation $(K M O=0.874$ Bartlett's Test of Sphericity: $\left.\chi^{2}(136)=1507.03 ; p<0.001\right)$. The number of factors was determined using parallel analysis, the Guttman-Kaiser criterion, and Cattell's scree test. Item retention was based on strict criteria for robust and stable factor structure (Osborne, 2008). Using an iterative process, items with communalities $<0.40$, factor loadings $<0.50$, and cross-loadings $>0.30$ were removed.

This analysis resulted in a 2-factor 12-item solution (Revised-SPIN; Table 2). Item 1 and 2 were removed because of low initial communalities, and items 6, 11 and 16 because of high cross-loadings. All the remaining items had high factor loadings on corresponding factors forming the first factor "observation situations and negative evaluation" ( $40 \%$ of the variance) and the second factor "social avoidance and fear" (13\% of the variance).

CFA was performed to evaluate the fitness of the structure derived by the EFA. The initial fit indices did not support the model, but correlating suggested error terms resulted in a very good fit (Table 1). The modification indices supported correlating error terms for items 10 and 4,8 and 3 , and 5 and 
(1) TABLE 2

Factor structure of the Revised-SPIN
12. These modifications were made in the one-factor structure and were justified, as aforementioned, due to the similarities in item content.

\begin{tabular}{|c|c|c|c|}
\hline Revised-SPIN item & $\mathrm{COM}$ & $\begin{array}{r}1 \text { st } \\
\text { factor }\end{array}$ & $\begin{array}{l}\text { 2nd } \\
\text { factor }\end{array}$ \\
\hline 1 I am afraid of people in authority & - & - & . \\
\hline 2 I am bothered by blushing in front of people & - & - & - \\
\hline 3 Parties and social events scare me & 0.55 & -0.02 & 0.75 \\
\hline 4 I avoid talking to people I don't know & 0.61 & -0.01 & 0.78 \\
\hline 5 Being criticized scares me a lot & 0.55 & 0.75 & -0.02 \\
\hline \multicolumn{4}{|l|}{6 Fear of embarrassment causes me to avoid doing } \\
\hline things or speaking to people & - & - & - \\
\hline 7 Sweating in front of people causes me distress & 0.42 & 0.59 & 0.11 \\
\hline 8 I avoid going to parties & 0.53 & -0.15 & 0.79 \\
\hline 9 I avoid activities in which I am the center of attention & 0.47 & 0.25 & 0.53 \\
\hline 10 Talking to strangers scares me & 0.58 & 0.07 & 0.73 \\
\hline 11 I avoid having to give speeches & - & - & - \\
\hline 12 I would do anything to avoid being criticized & 0.63 & 0.84 & -0.12 \\
\hline 13 Heart palpitations bother me when I am around people & 0.49 & 0.67 & 0.02 \\
\hline 14 I am afraid of doing things when people might be watching & 0.59 & 0.70 & 0.12 \\
\hline 15 Being embarrassed or looking stupid is among my worst fears & 0.59 & 0.78 & -0.02 \\
\hline 16 I avoid speaking to anyone in authority & - & - & - \\
\hline \multirow[t]{3}{*}{$17 \mathrm{Tr}$} & 0.50 & 0.73 & -0.06 \\
\hline & & 40.44 & 13.54 \\
\hline & & 4.85 & 1.63 \\
\hline
\end{tabular}

Note. COM: communality; 1st factor: observation situations and negative evaluation; 2 nd factor: social avoidance and fear

Finally, in order to assess convergent and divergent construct validity we calculated Pearson correlation coefficient between the SPIN total score and other theoretically similar tests - Brief-FNE, and the relevant but theoretically different test - BDI-II. A significant and strong correlation of SPIN and Brief-FNE $(r=0.60 ; p<0.001)$ showed support for convergent validity, and a significant but smaller correlation of SPIN and BDI-II $(r=0.39 ; p<0.001)$ showed support for divergent validity.

\section{Reliability}

The average inter-item correlation was moderate $(r=0.35$; $\left.r_{\min }=0.08 ; r_{\max }=0.69\right)$ and the average item-total correlation was strong $\left(r=0.56 ; r_{\min }=0.36 ; r_{\max }=0.70\right)$. Internal consistency measured by Cronbach's $\alpha$ coefficient was $0.90(95 \%$ CI $[0.88,0.92])$ for the one-dimensional structure and none of the items lowered the consistency of the entire scale. In the 2 -factor solution, the subscale "observation situations and negative evaluation" showed good internal consistency $(\alpha 1=0.85$; 
DRUŠ. ISTRAŽ. ZAGREB GOD. 24 (2015), BR. 3, STR. $407-426$

MARIČIĆ, A., ŠTAMBUK, M.: THE ROLE OF..
95\% CI [0.82, 0.88]) while for the subscale "social avoidance and fear" internal consistency was good considering the small number of items $(\alpha 2=0.77 ; 95 \%$ CI $[0.71,0.82])$. None of the items lowered the consistency of the corresponding subscale.

The test-retest reliability $(r=0.68, p<0.001)$, assessed by calculating the Pearson correlation coefficient between the results of the same subjects $(N=55)$ over 6 months, was high considering the time interval.

\section{The mediating role of loneliness in the relation of social anxiety and subjective well-being}

Descriptive statistics are presented in Table 3. SWB was negatively and significantly associated with all hypothesized predictors while its correlation with loneliness was the strongest.

(1) TABLE 3

Descriptive statistics for the study variables
Loneliness was positively and significantly associated with SA operationalized as the total SPIN score, as well as two factors of the Revised-SPIN.

\begin{tabular}{|c|c|c|c|c|c|c|c|c|}
\hline \multirow{2}{*}{$\frac{\text { Variable }}{\text { 1. Social anxiety }}$} & \multicolumn{2}{|c|}{ TR (full TR) } & \multirow{2}{*}{$\frac{M}{15.98}$} & \multirow{2}{*}{$\frac{S D}{10.34}$} & \multirow{2}{*}{1} & \multirow[t]{2}{*}{2} & \multirow[t]{2}{*}{3} & \multirow[t]{2}{*}{4} \\
\hline & $0-52$ & $(0-68)$ & & & & & & \\
\hline $\begin{array}{l}\text { 2. Observation situations and } \\
\text { negative evaluation }\end{array}$ & $0-25$ & $(0-28)$ & 8.01 & 5.42 & 0.91 & - & & \\
\hline 3. Social avoidance and fear & $0-15$ & $(0-20)$ & 3.07 & 2.97 & 0.77 & 0.51 & - & \\
\hline 4. Loneliness & $7-33$ & $(7-35)$ & 11.72 & 5.03 & 0.38 & 0.39 & 0.25 & - \\
\hline 5. Subjective well-being & $9-79$ & $(8-80)$ & 59.12 & 12.14 & -0.29 & -0.27 & -0.21 & -0.43 \\
\hline
\end{tabular}

Note. For all correlations $p<0.001$.

Responding to the second aim required testing models with a large number of manifest variables per latent variable in a moderately large sample. Following Little, Cunningham, Shahar, and Widaman's (2002) recommendations, instead of scale items we used three parcels per latent variable constructed by the item-to-construct balance technique.

To determine the mediation effect of loneliness we used structural equation modelling (SEM) with latent variables and the step-up strategy (Brown, 2006), which tests models from the most complex to the more constrained ones while checking for a significant drop in model fitness. First, we tested the model in which SA was represented as a one-dimensional construct (model A). Next, in order to test how different SA dimensions are related to SWB through loneliness, we tested the model in which it was represented with two factors of the Revised-SPIN (model B).

In the first step, we tested models where social anxiety 
DRUŠ. ISTRAŽ. ZAGREB GOD. 24 (2015), BR. 3 STR. $407-426$

MARIČIĆ, A., ŠTAMBUK, M. THE ROLE OF...

(1) FIGURE 1

Final structural models of relationships between social anxiety, loneliness and subjective well-being yielded a very good fit (Model A: $\chi^{2}(24)=33.99 ; p=0.085$; $\chi^{2} / d f=1.41 ; S R M R=0.04 ; C F I=0.99 ; T L I=0.98 ; R M S E A=0.05 ;$ Model B: $\chi^{2}(48)=53.68 ; p=0.266 ; \chi^{2} / d f=1.12 ; S R M R=0.04$; $C F I=0.99 ; T L I=0.99 ; R M S E A=0.03)$. Furthermore, the results demonstrated that, taking into account loneliness, the direct effects of social anxiety $(\beta=-0.13 ; p=0.17)$ and its components $(\beta 1=-0.04 ; p=0.72 ; \beta 2=-0.08 ; p=0.56$ ) on SWB were not significant. The next step involved testing the models' fitness without direct effects of social anxiety and its components on SWB. The testing resulted in a similarly good fit of both models which are, as the final ones, presented in Figure 1. In Model A, the relationship between SA and SWB was fully mediated by loneliness. In other words, social anxiety was related to lower SWB due to its relation to greater loneliness. Moreover, the results for Model B showed that the key aspect of social anxiety indirectly related to lower SWB through greater loneliness is the factor representing observation situations and negative evaluation, while social avoidance and fear was not related to loneliness nor to SWB.

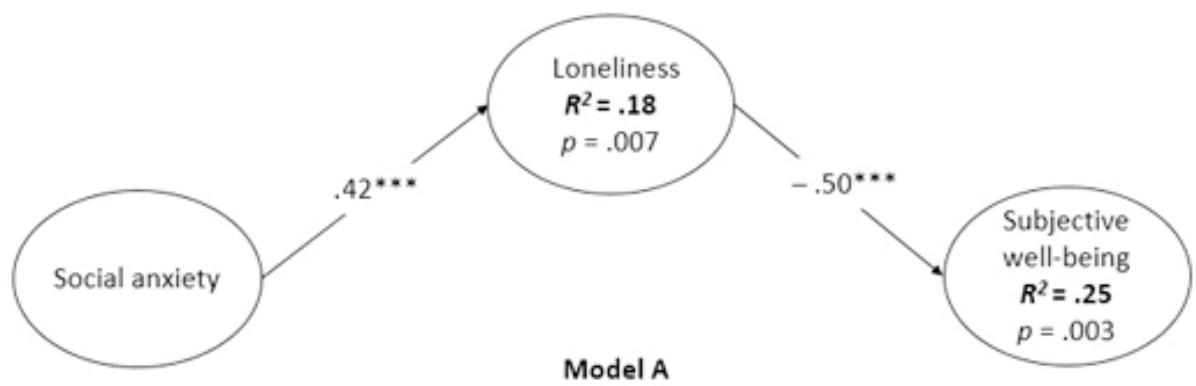

$\chi^{2}(25)=35.75 ; p=.075 ; \chi^{2} / d f=1.43 ;$ SRMR $=.05 ; C F I=.99 ; T L I=.98 ; R M S E A=.05$

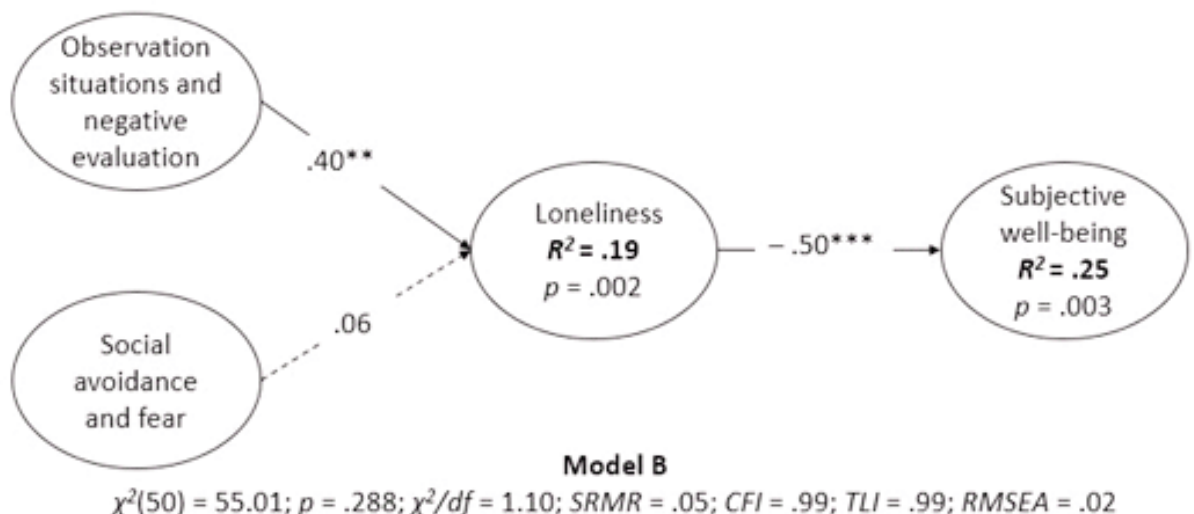

Note. Standardized path coefficients are shown. ${ }^{* *} p<0.001 ;{ }^{* *} p<0.01$.

The indirect effects' significance was tested with the delta method (MacKinnon, 2008, as cited in Muthén \& Muthén, 
DRUŠ. ISTRAŽ. ZAGREB GOD. 24 (2015), BR. 3, STR. $407-426$

MARIČIĆ, A., ŠTAMBUK, M.: THE ROLE OF.

\section{DISCUSSION}

\section{Psychometric properties of the SPIN}

Following recent research (e.g., Carleton et al., 2010), we used improved recommendation for conducting EFA (Osborne, 2008) and CFA, which should yield increasingly robust results in comparison to those used in earlier research (e.g., Connor et al., 2000). In accordance with the parsimony criterion, our results show reasonable support for the one-dimensional model. This is consistent with evidence of the total SPIN score having excellent internal consistency, test-retest reliability, convergent and discriminant validity as well as sensitivity to the SA severity changes following treatment (Antony et al., 2006; Radomsky et al., 2006). However, our results also show that several items may be redundant and that a 2-factor structure fits the current data better. Redundancy of certain items is somewhat expected based on the sound psychometric properties of Mini-SPIN (Connor et al., 2001) and recent findings (e.g., Carleton et al., 2010).

Although assessing the degree of discomfort during interaction with figures of authority is present in a number of SA measures (Caballo et al., 2013), our results suggest removing items with this content (no. 1 and 16). It may be that longterm education and identity development in the postcommunist context and largely collectively oriented community such as Croatia can make the discomfort while dealing with authority a more universal experience than one uniquely related to SA.

Another item suggested for exclusion refers to being bothered by blushing in front of people (no. 2), which may again represent a universal experience and not only an SA symptom. People blush following violation of social norms, but can also blush due to happiness or gratitude (Leary \& Toner, 2013). Moreover, in contrast to physiological symptoms like heart palpitations, blushing can be more easily noticed by others, and for that reason generally bother people and not only SA 
DRUŠ. ISTRAŽ. ZAGREB GOD. 24 (2015), BR. 3 STR. $407-426$

MARIČIĆ, A., ŠTAMBUK, M THE ROLE OF.. individuals. Finally, different findings emphasize that SA individuals vary extensively on blushing propensity, intensity and blushing concerns (Voncken \& Bögels, 2009).

Situations mentioned in item no. 6 and 11 (doing things, speaking to people and giving speeches) may not be unique for SA individuals. They seem to be an integral part of students' duties and unavoidable in their everyday life. Distress caused by these situations is experienced by most students since their academic achievement depends on dealing with them. Thus, participants from the general population may have a different understanding of these items.

As previously stated, the remaining items produced a reliable 2-factor Revised-SPIN containing 12 items that demonstrated fit indices superior to all of the other tested models. The first factor represents "observation situations and negative evaluation" and the second "social avoidance and fear". The first factor is comparable to the factor called "criticism and embarrassment" found in widely used SA measures and considered essential for the SA construct (Caballo et al., 2013). Likewise, factors resembling our second factor are consistently found in those instruments. Similar to other studies (e.g, Carleton et al., 2010), we have not found evidence that participants clearly discriminate avoidance and fear. Although theoretically distinct, these components can be easily confounded since avoidance is the main strategy in prevention and/or reduction of fear in SA individuals. Factors found in this study can be partially interpreted in line with Hughes and colleagues' (2006) distinction between performance-related (comparable to 1st factor) and social interaction-related concerns (comparable to 2nd factor). Items containing physiological symptoms did not emerge as a separate factor. This is expected since in some research the exclusion of these items was suggested (Carleton et al., 2010), or this factor also did not emerge (e.g., Gori et al., 2013). Also, of the three theoretically and clinically relevant subscales (fear, avoidance and physiology), physiology subscale showed the lowest levels of internal reliability and predictive power (Antony et al., 2006). Accordingly, it was suggested that the assessment of physiological symptoms does not contribute in discriminating individuals with and without $\mathrm{SA}$. Although, caution is warranted since attention biases toward internal physiology occur often in SA individuals (e.g., Clark, 2005), making the measuring of adequate physiological symptoms a challenging field for future research. In conclusion, this study contributes to the notion that clinically differentiated SA components are not crucial in measuring SA, and that distinct feared situations clusters seem more important. 
DRUŠ. ISTRAŽ. ZAGREB GOD. 24 (2015), BR. 3, STR. $407-426$

MARIČIĆ, A., ŠTAMBUK, M.: THE ROLE OF.
As expected, the correlation between SPIN total score and score on the theoretically assumed SA feature - fear of negative evaluation (Brief-FNE) - was significant and strong, showing support for convergent validity. A significant but smaller correlation with a relevant but theoretically different test measuring depression severity (BDI-II) was comparable to previous results (Sosic, Gieler, \& Stangier, 2008) and showed support for divergent validity. This moderate association is expected since the tripartite model states that anxiety and depression have shared as well as unique features (Clark \& Watson, 1991). Consistent with convergent and divergent total SPIN score validity, is the high level of internal consistency and test-retest reliability similar to those previously found (e.g., Garcia-Lopez et al., 2010).

\section{Social anxiety and subjective well-being: the role of loneliness}

The results from the present study show that the effect of social anxiety on SWB is fully mediated by loneliness: increased SA is associated with increased feelings of loneliness that is in turn associated with decreased SWB. These results correspond to the previous findings where lower SWB (e.g., Eng et al., 2005), as well as small social network (Falk Dahl \& Dahl, 2010), was more common in people with high SA. Additionally, for Croatian adolescents the feelings of loneliness were also negatively correlated with well-being (Nekić, 1998).

For the purpose of clearer understanding of the effects of social anxiety in everyday functioning, we further investigated how different SA symptoms contribute to its interrelations with loneliness and SWB. The key aspect of SA indirectly related to lower SWB through greater loneliness refers to observation situations and negative evaluation, while the dimension of social avoidance and fear is not related to loneliness nor to SWB. These findings may be explained by the fact that contrary to the former factor, the latter comprises avoidance and fear related to social activities that do not refer to intimate and close contacts, which is the most relevant aspect of loneliness. Baumeister and Leary (1995) argue that people feel lonely when their needs for regular social contact with those to whom one feels connected are not sufficiently met. Moreover, it appears that belongingness, rather than the number of social contacts, is the crucial aspect, which when not satisfied can cause pathological consequences beyond mere temporary distress and lower SWB (e.g., Kiecolt-Glaser et al., 1984). The dimension of observation situations and negative evaluation can refer to the range of social contacts, which can involve family members, friends, partners, as well as acquaintances, strangers and authority figures. 
DRUŠ. ISTRAŽ. ZAGREB GOD. 24 (2015), BR. 3 STR. $407-426$

MARIČIĆ, A., ŠTAMBUK, M. THE ROLE OF...
Considered together, it seems that SA does not pose a threat to SWB if it is not accompanied by the lack of meaningful social relationships. Moreover, SA symptoms that contribute to its relation with SWB through loneliness are those related to the concerns of being negatively evaluated or merely observed by others when experiencing or doing something, which can appear in formal as well as intimate interactions.

A general feeling of satisfaction with life varies according to symptom levels and disability in socially anxious populations (Eng et al., 2005). In addition to these findings, our study pointed out that different SA symptoms may contribute differently to SWB. Unsurprisingly, it seems that symptoms that affect closer relationships to a greater extent are associated to lower SWB. Knowing that, our results imply that focusing the therapy for SA more on developing close relationships may enhance positive treatment outcomes and higher SWB. Our findings are even more relevant since close relationships do not only influence SWB, but also have profound implications for health (e.g., Schoenbach, Kaplan, Fredman, \& Kleinbaum, 1986). Specifically, individuals with more social relationships are found to have better health and longevity. Keeping in mind the association between social relationships and physical and emotional well-being, further research on SA subtypes or its group of symptoms in this context are necessary.

\section{Limitations and direction for future research}

Several limitations of the present research can be useful guidelines for future research. First, results may be limited due to the female student sample. Although some findings imply that sex differences observed in other anxiety disorders are less pronounced in SA (McNeil, 2010), or do not exist (Craske, 2003), potentially important sex differences were found on some of the SPIN items (Carleton et al., 2010). It is reasonable to assume that in male or mixed samples a somewhat different factor structure could emerge. Second, a student sample, not having very high SA levels, may be limiting as well. However, many researchers agree that most of the findings related to the clinical samples operate in a similar fashion for non-clinical ones (e.g., Miskovic \& Schmidt, 2012). Third, a clinical comparison group could provide the opportunity to test the discriminant validity of the SPIN and establish cut-off scores in the Croatian population. Fourth, SPIN's instructions restrict the answers to situations from the past week, which may be limiting since some of the mentioned scenarios usually do not happen weekly (e.g., giving speeches). Finally, the presumed confounding of fear and avoidance warrant fur- 
DRUŠ. ISTRAŽ. ZAGREB GOD. 24 (2015), BR. 3, STR. $407-426$

MARIČIĆ, A., ŠTAMBUK, M.: THE ROLE OF..

\section{REFERENCES}

ther research. Qualitative methodology could be used to investigate participants' understanding of the items in question. Also, they could be evaluated if an explicit distinction described in SPIN's instructions or alterations in the wording of these items were to contribute to the distinction of fear and avoidance.

Alden, L. E., Regambal, M. J., \& Plasencia, L. (2014). Relational processes in social anxiety disorder. In J. Weeks (Eds.), Handbook on social anxiety disorder (pp. 159-178). Wiley-Blackwell Press. doi:10. 1002/9781118653920.ch8

Allen, R. L., \& Oshagan, H. (1995). The UCLA loneliness scale: Invariance of social structural characteristics. Personality and Individual Differences, 19(2), 185-195. doi:10.1016/0191-8869(95)00025-2

American Psychiatric Association (APA) (2013). Diagnostic and Statistical Manual of Mental Disorders, Fifth Edition. Arlington: American Psychiatric Association. doi:10.1176/appi.books.9780890425596

Antony, M. M., Coons, M. J., McCabe, R. E., Ashbaugh, A., \& Swinson, R. P. (2006). Psychometric properties of the social phobia inventory: Further evaluation. Behaviour Research and Therapy, 44(8), 1177-1185. doi:10.1016/j.brat.2005.08.013

Baumeister, R. F., \& Leary, M. R. (1995). The need to belong: Desire for interpersonal attachments as a fundamental human motivation. Psychological Bulletin, 117(3), 497-529. doi:10.1037/0033-2909.117.3.497

Beck, A. T., Steer, R. A., \& Brown, G. K. (2011). Manual for the Beck Depression Inventory-II. Jastrebarsko: Naklada Slap.

Bezinović, P. (1988). Percepcija osobne nekompetentnosti kao dimenzija samopoimanja. [Perception of self-incompetence as a dimension of self-concept]. (Unpublished doctoral dissertation). University of Zagreb, Zagreb.

Brown, T. A. (2006). Confirmatory factor analysis for applied research. New York \& London: The Guilford Press.

Caballo, V. E., Salazar, I. C., Irurtia, M. J., Arias, B., \& Nobre, L. (2013). The assessment of social anxiety through five self-report measures, LSAS-SR, SPAI, SPIN, SPS, and SIAS: A critical analysis of their factor structure. Behavioral Psychology/Psicología Conductual, 21(3), 423-448. Available at http://www.researchgate.net

Carleton, R. N., Collimore, K. C., Asmundson, G. J. G., McCabe, R. E., Rowa, K., \& Antony, M. M. (2010). SPINning factors: Factor analytic evaluation of the Social Phobia Inventory in clinical and nonclinical undergraduate samples. Journal of Anxiety Disorders, 24(1), 94-101. doi:10. 1016/j.janxdis.2009.09.003

Chou, K. L., Liang, K., \& Sareen, J. (2011). The association between social isolation and the DSM-IV mood, anxiety, and substance use disorders: Wave 2 of the National Epidemiologic Survey on Alcohol and Related Conditions. Journal of Clinical Psychiatry, 72(11), 1468-1476. doi:10.4088/JCP.10m06019gry

Clark, D. M. (2005). A cognitive perspective on social phobia. In W. Ray, W. R. Crozicr, \& L. L. Alden (Eds.), The essential handbook of social 
DRUŠ. ISTRAŽ. ZAGREB GOD. 24 (2015), BR. 3 STR. $407-426$

MARIČIĆ, A., ŠTAMBUK, M. THE ROLE OF... anxiety for clinicians (pp. 193-218). Chichester: John Wiley \& Sons Ltd. doi:10.1016/S0006-3223(97)87445-8

Clark, L. A., \& Watson, D. (1991). Tripartite model of anxiety and depression: Psychometric evidence and taxonomic implications. Journal of Abnormal Psychology, 100(3), 316-336. doi:10.1037/0021-843X.100.3.316

Connor, K. M., Davidson, J. R., Churchill, L. E., Sherwood, A., Weisler, R. H., \& Foa, E. (2000). Psychometric properties of the Social Phobia Inventory (SPIN) New self-rating scale. The British Journal of Psychiatry, 176(4), 379-386. doi:10.1192/bjp.176.4.379

Connor, K. M., Kobak, K. A., Churchill, L. E., Katzelnick, D., \& Davidson, J. R. (2001). Mini-SPIN: A brief screening assessment for generalized social anxiety disorder. Depression and Anxiety, 14(2), 137-140. doi:10.1002/da.1055

Cox, B. J., Clara, I. P., Sareen, J., \& Stein, M. B. (2008). The structure of feared social situations among individuals with a lifetime diagnosis of social anxiety disorder in two independent nationally representative mental health surveys. Behaviour Research and Therapy, 46(4), 477-486. doi:10.1016/j.brat.2008.01.011

Craske, M. G. (2003). Origins of phobias and anxiety disorders: Why more women than men? Oxford, UK: Elsevier.

Cummins, R. A., Eckersley, R., Pallant, J., Van Vugt, J., \& Misajon, R. A. (2003). Developing a national index of subjective wellbeing: The Australian unity wellbeing index. Social Indicators Research, 64(2), 159-190. doi:10.1023/A:1024704320683

Diener, E., \& Biswas-Diener, R. (2008). Happiness: Unlocking the mysteries of psychological wealth. Malden, MA: Blackwell Publishing. doi:10. 1002/9781444305159

Diener, E., Nickerson, C., Lucas, R. E., \& Sandvik, E. (2002). Dispositional affect and job outcomes. Social Indicators Research, 59(3), 229-259. doi:10.1023/A:1019672513984

Diener, E. R., \& Ryan, K. (2009). Subjective well-being: A general overview. South African Journal of Psychology, 39(4), 391-406. doi:10. 1177/008124630903900402

Eng, W., Coles, M. E., Heimberg, R. G., \& Safren, S. A. (2005). Domains of life satisfaction in social anxiety disorder: Relation to symptoms and response to cognitive-behavioral therapy. Journal of Anxiety Disorders, 19(2), 143-156. doi:10.1016/j.janxdis.2004.01.007

Falk Dahl, C. A., \& Dahl, A. A. (2010). Lifestyle and social network in individuals with high levels of social phobia/anxiety symptoms: A community-based study. Social Psychiatry and Psychiatric Epidemiolo$g y, 45(3)$, 309-317. doi:10.1007/s00127-009-0069-6

Garcia-Lopez, L. J., Bermejo, R. M., \& Hidalgo, M. (2010). The Social Phobia Inventory: Screening and cross-cultural validation in Spanish adolescents. The Spanish Journal of Psychology, 13(2), 970-980. doi:10. 1017/S1138741600002614

Gori, A., Giannini, M., Socci, S., Luca, M., Dewey, D., Schuldberg, D., \& Craparo, G. (2013). Assessing social anxiety disorder: Psychometric properties of the Italian Social Phobia Inventory (I-SPIN). Clinical Neuropsychiatry, 10(1), 37-42. Available at http://scholarworks.umt. edu/psych_pubs/11/ 
DRUŠ. ISTRAŽ. ZAGREB GOD. 24 (2015), BR. 3, STR. $407-426$

MARIČIĆ, A., ŠTAMBUK, M.: THE ROLE OF..
Holt, C. S., Heimberg, R. G., \& Hope, D. A. (1992). Avoidant personality disorder and the generalized subtype of social phobia. Journal of Abnormal Psychology, 101(2), 318-325. doi:10.1037/0021-843X.101.2.318

Hu, L. T., \& Bentler, P. M. (1999). Cutoff criteria for fit indexes in covariance structure analysis: Conventional criteria versus new alternatives. Structural Equation Modeling: A Multidisciplinary Journal, 6(1), 1-55. doi:10.1080/10705519909540118

Hughes, A. A., Heimberg, R. G., Coles, M. E., Gibb, B. E., Liebowitz, M. R., \& Schneier, F. R. (2006). Relations of the factors of the tripartite model of anxiety and depression to types of social anxiety. Behaviour Research and Therapy, 44(11), 1629-1641. doi:10.1016/j.brat.2005.10.015

International Wellbeing Group (2013). Personal Wellbeing Index: 5th Edition. Melbourne: Australian Centre on Quality of Life, Deakin University.

Jakšić, N., Ivezić, E., Jokić-Begić, N., Surányi, Z., \& Stojanović-Špehar, S. (2013). Factorial and diagnostic validity of the Beck Depression Inventory-II (BDI-II) in Croatian primary health care. Journal of Clinical Psychology in Medical Settings, 20(3), 311-322. doi:10.1007/s108 80-013-9363-2

Kahneman, D., \& Krueger, A. B. (2006). Developments in the measurement of subjective well-being. Journal of Economic Perspectives, 20(1), 3-24. doi:10.1257/089533006776526030

Kenny, D. A. (2014). Mediation: Effect size of the indirect effect and the computation of power. Available at http://davidakenny.net/cm/mediate.htm. doi:10.1002/9781118445112.stat06605

Kessler, R. C., Berglund, P., Demler, O., Jin, R., Merikangas, K. R., \& Walters, E. E. (2005). Lifetime prevalence and age-of-onset distributions of DSM-IV disorders in the National Comorbidity Survey Replication. Archives of General Psychiatry, 62(6), 593-602. doi:10.1001/arch psyc.62.6.593

Kiecolt-Glaser, J. K., Garner, W., Speicher, C., Penn, G. M., Holliday, J., \& Glaser, R. (1984). Psychosocial modifiers of immunocompetence in medical students. Psychosomatic Medicine, 46, 7-14. doi:10.1097/ 00006842-198401000-00003

Lacković-Grgin, K., Penezić, Z., \& Nekić, M. (2002). Kratka verzija UCLA skale usamljenosti [The short version of UCLA loneliness scale]. In K. Lacković-Grgin, A. Proroković, V. Cubela, \& Z. Penezić (Eds.), Zbirka psihologijskih skala i upitnika, svezak 1 [Collection of psychological scales and questionnaires, Volume 1] (pp. 77-78). Zadar: University of Zadar.

Lampe, L., Slade, T., Issakidis, C., \& Andrews, G. (2003). Social phobia in the Australian National Survey of Mental Health and Well-Being (NSMHWB). Psychological Medicine, 33(4), 637-646. doi:10.1017/ S0033291703007621

Leary, M. R. (1983). A brief version of the Fear of Negative Evaluation Scale. Personality and Social Psychology Bulletin, 9(3), 371-375. doi:10. 1177/0146167283093007

Leary, M. R., \& Toner, K. (2013). Psychological theories of blushing. In W. Crozier \& P. J. de Jong (Eds.), The psychological significance of the blush (pp. 63-76). New York: Cambridge University Press. doi:10. 1017/CBO9781139012850.007 
DRUŠ. ISTRAŽ. ZAGREB GOD. 24 (2015), BR. 3 STR. $407-426$

MARIČIĆ, A., ŠTAMBUK, M. THE ROLE OF...
Letamendi, A. M., Chavira, D. A., \& Stein, M. B. (2009). Issues in the assessment of social phobia: A review. The Israel Journal of Psychiatry and Related Sciences, 46(1), 13. Available at http://www.ncbi.nlm.nih. gov/pmc/articles/PMC2925842/

Little, T. D., Cunningham, W. A., Shahar, G., \& Widaman, K. F. (2002). To parcel or not to parcel: Exploring the question, weighing the merits. Structural Equation Modelling, 9(2), 151-173. doi:10.1207/S1532800 7SEM0902_1

McNeil, D. W. (2010). Evolution of terminology and constructs in social anxiety and its disorders. In S. G. Hofmann, \& P. M. DiBartolo (Eds.), Social anxiety: Clinical, developmental, and social perspectives (pp. 3-21). New York: Academic Press. doi:10.1016/B978-0-12-3750969.00 $001-8$

Miskovic, V., \& Schmidt, L. A. (2012). Social fearfulness in the human brain. Neuroscience \& Biobehavioral Reviews, 36(1), 459-478. doi:10. 1016/j.neubiorev.2011.08.002

Morrison, A. S., \& Heimberg, R. G. (2013). Social anxiety and social anxiety disorder. Annual Review of Clinical Psychology, 9, 249-274. doi:10. 1146/annurev-clinpsy-050212-185631

Muthén, L. K. i Muthén, B. O. (2010). Mplus User's Guide (6th Edition). Los Angeles: Muthén \& Muthén.

Nagata, T., Nakajima, T., Teo, A. R., Yamada, H., \& Yoshimura, C. (2013). Psychometric properties of the Japanese version of the Social Phobia Inventory. Psychiatry and Clinical Neurosciences, 67(3), 160-166. doi:10.1111/pcn.12037

Nekić, M. (1998). Usamljenost i samoća: njihovi korelati u kasnijoj adolescenciji [Loneliness and solitude: Their correlates in later adolescence]. (Unpublished graduate thesis). University of Zadar, Zadar.

Osborne, J. W. (2008). Best practices in quantitative methods. Los Angeles: Sage Publications Inc.

Radomsky, A. S., Ashbaugh, A. R., Saxe, M. L., Ouimet, A. J., Golden, E. R., Lavoie, S. L., \& O'Connor, K. P. (2006). Psychometric properties of the French and English versions of the Social Phobia Inventory. Canadian Journal of Behavioural Science/Revue canadienne des sciences du comportement, 38(4), 354-360. doi:10.1037/cjbs2006021

Ruscio, A. M., Brown, T. A., Chiu, W. T., Sareen, J., Stein, M. B., \& Kessler, R. C. (2008). Social fears and social phobia in the USA: Results from the National Comorbidity Survey Replication. Psychological Medicine, 38(1), 15-28. doi:10.1017/S0033291707001699

Schoenbach, V. J., Kaplan, B. H., Fredman, L., \& Kleinbaum, D. G. (1986). Social ties and mortality in Evans County, Georgia. American Journal of Epidemiology, 123(4), 577-591. Available at: http://aje.oxford journals.org/content/123/4/577.short

Sosic, Z., Gieler, U., \& Stangier, U. (2008). Screening for social phobia in medical in-and outpatients with the German version of the Social Phobia Inventory (SPIN). Journal of Anxiety Disorders, 22(5), 849-859. doi:10.1016/j.janxdis.2007.08.011

Teo, A. R., Lerrigo, R., \& Rogers, M. A. (2013). The role of social isolation in social anxiety disorder: A systematic review and meta- 
DRUŠ. ISTRAŽ. ZAGREB GOD. 24 (2015), BR. 3, STR. $407-426$

MARIČIĆ, A., ŠTAMBUK, M.: THE ROLE OF. analysis. Journal of Anxiety Disorders, 27(4), 353-364. doi:10.1016/j.janxdis. 2013.03.010

Toit, P. L., \& Stein, D. J. (2003). Social anxiety disorder. In D. Nutt, \& J. C. Ballanger (Eds.), Anxiety disorders (pp. 39-50). Malden, MA: Blackwell, Sceince, Ltd. doi:10.1002/9780470986844.ch7

Tov, W., \& Diener, E. (2008). The well-being of nations: Linking together trust, cooperation, and democracy. In B.A. Sullivan, M. Snyder, \& J. L. Sullivan (Eds.), Cooperation: The political psychology of effective human interaction (pp. 323-342). Malden, MA: Blackwell Publishing. doi:10.1007/978-90-481-2350-6_7

Voncken, M. J., \& Bögels, S. M. (2009). Physiological blushing in social anxiety disorder patients with and without blushing complaints: Two subtypes? Biological Psychology, 81(2), 86-94. doi:10.1016/ j.biopsycho.2009.02.004

Wang, P. S., Lane, M., Olfson, M., Pincus, H. A., Wells, K. B., \& Kessler, R. C. (2005). Twelve-month use of mental health services in the United States: Results from the National Comorbidity Survey Replication. Archives of General Psychiatry, 62(6), 629-640. doi:10.1001/archpsyc.62.6.629

\section{Uloga osamljenosti u odnosu socijalne anksioznosti i subjektivne dobrobiti: upotreba Inventara socijalne fobije (SPIN) kao mjere}

Antonija MARIČIĆ, Marina ŠTAMBUK

Hrvatski studiii, Zagreb

Svrha ovog istraživanja bila je ispitati medijacijsku ulogu osamljenosti između socijalne anksioznosti i subjektivne dobrobiti, uzimajući pri tome $u$ obzir multidimenzionalnost socijalne anksioznosti. Postizanju ovoga cilja prethodilo je ispitivanje psihometrijskih svojstava hrvatskoga prijevoda SPIN-skale na uzorku od 202 studentice. Rezultati pokazuju potporu jednodimenzionalnoj strukturi SPIN-a. Međutim, pokazalo se i to da nekoliko čestica može biti suvišno i da dvofaktorska struktura (12 čestica) bolje pristaje dobivenim podacima. Prvi je faktor opisan kao "situacije promatranja i negativne evaluacije", a drugi predstavlja "društveno izbjegavanje i strah". Ukupni SPIN-rezultat pokazao je konvergentnu i divergentnu konstruktnu valjanost, kao i visoku razinu unutarnje konzistencije i test-retest pouzdanosti. Osamljenost potpuno posreduje u odnosu socijalne anksioznosti i subjektivne dobrobiti. Simptomi socijalne anksioznosti koji pridonose njezinu odnosu sa subjektivnom dobrobiti kroz osamlienost jesu oni koji se odnose na zabrinutost vezanu uz negativnu evaluaciju ili promatranje od strane drugih kada osoba nešto doživljava ili radi.

Ključne riječi: socijalna anksioznost, SPIN, osamljenost, subjektivna dobrobit 